\title{
Ungdom som etterlatte ved selvmord Hvilken hjelp og støtte ønsker de? ${ }^{1)}$
}

Ved Kari Dyregrov

\begin{abstract}
"Det er veldig få som kan gå gjennom sånne ting uten å få hjelp. Jeg tror de fleste må ha hjelp. Det tror jeg. Jeg tror uansett at det er viktig å snakke med noen utenfor familien".
\end{abstract}

Sitatet er hentet fra en 17-åring som mistet sin søster ved selvmord, og som representerer en av de mange unge etterlatte i Norge hvert år. Med utgangspunkt i at det i 2005 ble registrert 533 selvmord i Norge, 360 menn og 173 kvinner (SSB, 2008), vet vi at også mange barn og unge blir tilbake etter tapet av en nærstående person. Forskning har vist at selvmord er en ekstremt belastende hendelse for de nærmeste etterlatte lenge etter selvmordet (Brent et al., 1996; Dyregrov, 2003). Mens det finnes noe kunnskap om unge etterlattes situasjon, vet man svært lite om hvordan de ønsker å bli møtt av fagfolk og andre (Dyregrov, 2005; Ranheim, 2002; Wertheimer, 1999). For å gi økt fokus til dette gjennomførte Landsforeningen for etterlatte ved selvmord (LEVE) prosjektet "Styrket omsorgsapparat for unge etterlatte ved selvmord". Prosjektet bestod av tre trinn: en aksjonsdel (helgesamlinger med unge etterlatte), en forskningsdel (som artikkelen omhandler og forfatteren var ansvarlig for) og en informasjonsdel (informasjon til potensielle støttemiljøer om hvordan de kan støtte de unge etter selvmord). Prosjektet ble gjennomført ved hjelp av midler fra Stiftelsen Helse og Rehabilitering.

\section{Et forskningsprosjekt}

Målet for forskningsdelen var å kartlegge unges psykososiale situasjon, samt deres erfaringer med hjelp og støtte fra helsevesenet, skolen, familie og venner og andre unge etterlatte. Et viktig fokus var om studiens informanter ville ha ønsket eventuell hjelp annerledes, og i så fall hvordan mht. innhold, omfang og kvalitet. I tillegg ble selvhjelpsstrategier og personlig vekst registrert.

Forskningsdelen ble gjennomført i 2004-2005. Trettito unge etterlatte fylte ut spørreskjema, mens 30 av dem også deltok i 11 fokusgruppeintervju (Bloom et al., 2001). De unge repre- senterte alle landets regioner, begge kjønn ( 1/ 3 gutter, 2/ 3 jenter), og alderen varierte mellom 13 og 24 år ( 18 år i gjennomsnitt). M ens åtte gikk i grunnskolen, var 16 i videregående skole, og åtte studerte ved høgskole/ universitet. Seks hadde mistet mor/ far, $22 \mathrm{bror} / \mathrm{s} ø$ ster og fire hadde mistet andre nære slektninger/ venner. Tiden siden dødsfallene varierte mellom en måned og sju år ( gjennomsnitt tre år). U tvalget ble dannet via helgesamlingene, gjennom annonser i dagspresse, gjennom skole og helsesøstertjeneste, og via LEVEs medlemsblad. En intervjuguide sikret at målsettingens kvalitative aspekt systematisk ble berørt. $0 \mathrm{~m}$ fanget av mottatt og ønsket hjelp ble kartlagt via et fire siders "H jelpskjema" utarbeidet ved Senter for Krisepsykologi. Posttraumatiske reaksjoner ble målt gjennom Impact of Event Scale (IES-15), beståen de av de to delskalaene for unngåelsesatferd og invaderende tanker/ minner (H orowitz et al., 1979), mens sorgreaksjoner og personlig vekst ble kartlagt via Hogan Sibling Inventor y of Bereavement ( $\mathrm{HSIB}$ )

(Hogan, 1990). Denne artikkelen presenterer noen resultater ved de unges situasjon, samt behov for hjelp fra fagfolk, slik de unge opplevde det (se også Dyregrov, 2006a, 2006b) .

\section{Unge sliter etter selvmord}

Studiens unge selvmordsetterlatte slet i betydelig grad lenge etter selvmordet. Frustrasjon, selvmordstanker, kroppslig uro knyttet til minner om hendelsen, depressive tanker og følelser eller angst ble hyppig rapportert gjennom intervjuene. De fleste fortalte at de fungerte dårligere i dagliglivet ( sov dårlig, endret spisemønster, isolerte seg fra venner, fikk skolevansker), og noen beskrev redusert selvbilde og identitetskrise (usikre sammen med venner, ikke "mentalt til stede", "ble plutselig voksen"). O mtrent hal vparten avinformantene slet med posttraumatiske stressreaksjoner i bekymringsfull grad i form av invaderende minner og bilder, eller gjennom unngåelse av alt som minnet om selvmordet ( målt ved IES). Dette viste seg ved at gjennomsnittsskåren på IES-15 var 36, og halvparten av de unge hadde posttraumatiske stressreaksjoner over en grenseverdi på 35 for IES-15. (Skåringer over dette nivået indikerer høy grad av posttraumatisk stress.) De som hadde mistet en nærstående relativt nylig ( $\leq 14$ måneder), slet mer enn de som hadde mistet for lengre tid siden (>14 måneder). Dette viste seg gjennom resultatene for delskalaene for invaderende minner ( gjennomsnitt henholdsvis 23 og 17) , og unngåelsesreaksjoner ( gjennomsnitt henholdsvis 24 og 17) (for mer informasjon se Dyregrov, 2008).

De posttraumatiske reaksjonene, som inkluderte flashbacks ( påtrengende sanseinntrykk fra hendelsen/ avdøde), vansker med å konsentrere seg og søvnproblemer eller mareritt, ble utdypet gjennom intervjuene. En ungdom uttrykte vanlige konsentrasjon sproblemer pga. invaderende tanker og grubling omkring det som skjedde slik:

Det kommer hele tiden sånnetanker om hva som skjedde akku rat når det skjedde, hvordan det var han tenkte, hvorfor det skjedde... .

Periodevis resulterte reaksjonene i mangel på energi med økt forekomst av fysisk sykdom og/ eller sosial tilbaketrekking. Alle de unge hadde konsentrasjonsvansker, og $43 \%$ oppga at de "nesten alltid" hadde slike vansker. På to av utsagnene i spørreskjemaet H SIB om at "Jeg vil dø slik at jeg kan være sammen med ham/ henne" og "Jeg tenker at jeg skulle vært død og han/ hun skulle levd", svarte åtte personer ( $25 \%$ ) at dette var "ganske ofte" eller "nesten alltid riktig". En ung jente uttalte: 


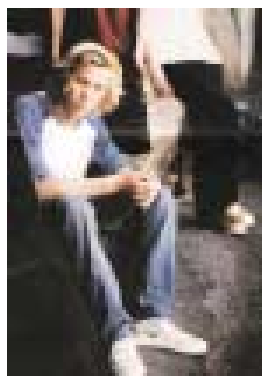

Nå når jeg har det så tungt, så har jeg ikke lyst å leve på en måte.

Flere unge påpekte at man ikke kan nevne slike tanker for foreldre, som "er livredde for at noe mer forferdelig skal skje" eller "har mer enn nok med seg selv". Mest utbredt var skolevansker. Gjennom inter viuene fortalte samtlige av informantene at de hadde, eller hadde hatt, vansker med å lære nytt og å konsentrere seg på skolen etter selvmordet. Spesielt når det var stille i timen, eller ved lekselesing hjemme presset tanker seg på, med mye grubling om hvorfor selvmordet hadde skjedd. De unge trengte mer tid og grundigere forklaringer enn før for à lære nye og vanskelige ting, jfr. en gutt på 14 år:

Det blir bare sånn at en klarer ikke gangetabellen en gang, ikke sant. Det tar mye len gre tid for meg, altså, få inn at det regnestykket er sånn.

$0 \mathrm{~g} \mathrm{jeg} \mathrm{trenger} \mathrm{mye} \mathrm{bedre} \mathrm{forklaring.}$

Mange av de unge fortalte om økt skolefravær og svakere karakterer pga. dårlig søvn med mareritt, nedsatt allmenntilstand og sykdom. Etter som tiden gikk, økte problemene i takt med at omverdenen gradvis glemte hva de hadde opplevd. $\varnothing$ kende modenhetsgrad gjorde at informantene hadde behov for å forstå og snakke om det som hadde skjedd - lenge etter at alle trodde de hadde "glemt". Informantene ønsket at lærerne i større grad kunne forstå hva de slet med, og hadde mange tanker om og forslag til hvordan skolen bedre kunne hjelpe dem (se Dyregrov, 2006a).

\section{Mangelfull støtte i forhold til opplevd behov}

De unge fortalte om sønderknuste foreldre som hadde vært ute av stand til å gi dem støtte og omsorg i lang tid etter selvmordet. I stedet hadde mange av informantene måttet overta foreldreroller overfor mindre søsken, eller omsorgsroller for foreldre den første tiden. En 19-årig jente sa:
Jeg kunne ikke tatt imot støtte fra mamma eller familien den tiden, det haddeikkefunket. For du ser at hun har det så vondt, og du har ikkelyst. Jeg måtte mate mamma det første døgnet, jeg kunneikke, det funket ikke det.

Flesteparten mente at ungdom vil trenge støtte og hjelp utenfor familien etter et selvmord. Gjennom "H jelpskjemaet" anga $69 \%$ av de unge at de opplevde behov for hjelp fra fagfolk i svært stor/ nokså stor/ viss grad, mens henholdsvis $19 \%$ og $12 \%$ i liten eller ingen grad hadde behov for slik hjelp. Sterkest behov for hjelp hadde jenter; de som savnet støtte fra familien, isolerte seg, hadde høy grad av påtrengende minner (intrusjon), og sterkeste sorgreaksjoner. Disse benyttet også i større grad "en person de kunne fortelle alt til". I nter vjudataene indikerte økte belastninger hos unge som hadde mistet foreldre eller søsken ift. de få som hadde annen relasjon til avdøde. De unges sorg og krisereaksjoner bar dessuten preg av større grad av uvirkelighet og sjokk når det var kort tid siden dødsfallet, mens savn ble mer utpreget etter en tid.

\section{Ønsker om hjelp fra fagfolk}

Gjennom intervjuene og åpne spørsmål i "H jelpskjemaet" ga de unge detaljerte beskrivelser av hvilken hjelp de ønsket fra fagfolk, jfr.:

Det burde jo være et team som på en måte til enhver tid står klar til å hjelpe hvis det har skjedd noe. For du vet jo aldri når du kan trenge hjelp. Går du på en knekk, så lønner det seg å få hjelp for at du skal komme deg fortest mulig på beina og sånn... altså du selv skal slippe å måtte ta kontakt. Det er mange som sliter veldig mye for å få den hjelpen de tren ger. Det burde være automatisk at presten, lege, politi, ambulanse tar kontakt med det teamet og sånneting, synes jeg. De burde kommet tilbake flere ganger.
Sitatet er hentet fra en ung mann som mistet sin eldre bror ved selvmord, og sammenfatter viktige forhold omkring unges behov for hjelp. Men selv om de fleste ønsket rutinemessig profesjonell hjelp, ba de om at dette måtte skje i samråd med og være tilpasset den enkeltes behov for hjelp. Videre oppfordret de hjelperne til ikke å spørre om unge etterlatte trenger hjelp - de må bare tilby den. De hevdet at fordi man i starten er fullstendig i sjokk, og "ikke vet opp eller ned på situasjonen", vet man heller ikke hva man trenger eller hva som finnes av hjelp. Mange følte stor usikkerhet i forhold til egne reaksjoner fordi reaksjonene var så sterke, og de ikke visste hvor det kunne ende. De ønsket derfor visshet for at "noen" sto klare til å hjelpe dem hvis de skulle komme til å trenge det - som en "livbøye". De unge foreslo at dersom ungdom avslår hjelp, fordi det er for tidlig, eller man ikke skjønner vitsen ved det, burde man få et visittkort, slik at hjelperne kunne nås ved en senere anledning. Men det beste ville være at hjelperne selv tok kontakt på et senere tidspunkt, jfr. en 17-årig jente:

Debu rde kommet tilbakeflere ganger. $\mathrm{N}$ oen trenger hjelp der og da, mens andre har lyst å ta det litt innover seg og roe det helt ned og prøveå finnelitt ut av det selv.

Betydningen avat fagfolk informerte og inkluderte de unge på en direkte og empatisk måte, ble vektlagt. Ved eventuelle leteaksjoner og senere når selvmordet er bekreftet, må man ikke holdes utenfor det som resten av familien får av opplysninger om selvmordet. De unge ønsket også informasjon om hva som har skjedd, om innhold i eventuelle avskjedsbrev og hva som skal skje videre. På et senere tidspunkt er det ønskelig med informasjon om normale reaksjoner når man mister nærstående ved selvmord. De unge ønsket hjelp fra kvalifiserte fagfolk; særlig samtalehjelp med psykolog, helsesøster og ( sosial) lærere ble etterlyst. Noen unge hadde hatt foreldre med på samtaler med psykolog, prest, lege osv., andre ikke. Ingen av dem sa at de hadde savnet å ha foreldre med 
under sine samtaler, men mange hadde savnet muligheten til å snakke med en fagperson på tomannshånd. De antok at de da lettere hadde kunnet si alt som plaget dem, også det som de ville skåne foreldre eller søsken fra å høre. De unge ba om at alle sentrale hjelpeinstanser etter selvmord (prest, politi, lege, lærere og begravel sesbyrå osv.) i større grad rettet oppmerksomhet mot unge etterlattes situasjon, basert på nødvendige kvalifikasjoner for å møte dem.

\section{"Med god kjemi kan vi presses litt mer"}

Et gjennomgangstema blant de unge var at "kjemien må stemme for at hjelpen skal nå frem". Dette innebar bl.a. at fagpersonen måtte være oppriktig interessert og til stede gjennom empati og kompetanse. Var ikke slike forutsetninger til stede, avsluttet de unge fort kontakten ( se Dyregrov, 2006b). Mange unge innså også at de selv hadde medvirket til at de ikke hadde fått den hjelpen de i ettertid kunne ha ønsket seg. De var ikke alltid så flinke til å uttr ykke seg og gi hjelperne beskjed om at de ikke hadde det godt. Fordi de unge av ulike grunner prøvde å skjule det, innså de at det heller ikke var lett for andre rundt å hjelpe dem. Noen hadde avslått hjelp som var tilbudt, og om dette sa flere: "Push oss litt mer og gjenta tilbud om hjelp. H jelperne må tore å være litt mer offensive, og ikke bare ta den første avisningen for god fisk." Andre som aldri hadde fått hjelp, tenkte at det ville kunne være vanskelig å ta imot tilbud, men mente de ville ha gjort det dersom tillitsvekkende fagfolk hadde motivert dem. Men en del unge var også skeptiske til å bli presset for fort til å åpne seg (for mye), jfr. en ungdom:

Den psykologen jeg hadde, skulle liksom få meg til à si absolutt alt. Jeg ville egentlig ikkesi så veldig mye, men han fikk meg faktisk til å si veldig mye. Så det er sikkert det som ødela det at jeg ikke fikk den hjelpen jeg tren gte. Kanskje ikke presse, men på en måtelitt presse, finne slurepunktet liksom. M en vi må være med å bestemme.

\section{De unges ønsker for hjelp fra fagfolk}

Fleksibilitet som hovedregel - slippe å få noe "trædd ned over hodet"

Automatisk tilbud om hjelp - slippe å lete frem og be om hjelp

Tidlig hjelp, som gjentas ved skiftende behov over tid

Hjelp i beredskap hvis/når man trenger det

Samtalehjelp fra kvalifiserte fagfolk - og kjemien må stemme

Ønsker eget fokus/individuelle samtaler - for å kunne snakke fritt

Informasjon om hendelsen - ikke holdes utenfor

Informasjon om/kobling til LEVE - for å møte unge i samme situasjon

De unge etterlatte innrømmet at det ikke vil være lett for fagfolk eller familiemedlemmer å finne "sl urepunktet", eller å vite hvor mye de skal "pushe" den enkelte unge for å gi den hjelpen de trenger og/ eller klarer å ta imot. Mange fortalte at de måtte skyve reaksjoner unna i starten, for i det hele tatt å være i stand til å holde seg oppe like etter selvmordet. De måtte ta virkeligheten inn litt etter litt, og da klarte de ikke å forholde seg til velvillige hjelpere eller familiemedlemmer som intenst ville hjelpe. Nær værelse og gjentatte forsiktige tilbud om hjelp ville derfor være løsningen, mente mange. $\mathrm{H}$ alvparten av ungdommene hadde snakket godt med helsesøster eller sosiallærer, som fungerte som et lavterskeltilbud fordi de var stasjonert ved skolene. En jente som var 16 år da far tok livet sitt sa:

Det er så fint at du kan gå bort og snakke ( med skolehelsesøster) hvis du har behov for det, det er veldig greit å vite hvis det skulle dukke opp noe. Det er så lite som skal til, og det er så lett å føle seg helt alene, men det er så lite som skal til for at du ikke føler det.

Sist, men ikke minst, ble ønske om kontakt med LEVE nevnt når informantene ble spurt om hvilken støtte de trengte, og hvilke råd for hjelp til selvhjelp de ville gi annen ungdom i samme situasjon. Undersøkelsens unge hadde fått vite om LEVEs ungdomssamlinger fra helsesøster eller andre i hjel peapparatet, og mente at slikt samarbeid mellom hjel peapparatet og LEVE burde styrkes.

\section{Noen refleksjoner omkring resultatene}

Studien bekrefter tidligere funn om at unge sliter med psykososiale vansker og posttraumatiske etterreaksjoner lenge etter selvmordet (Sethi \& Bhargava, 2003). Det ses klare likhetstrekk mellom gjennomsnittsskårene på IES15 i denne studien og tilsvarende unge i en tidligere norsk landsdekkende undersøkelse av etterlatte ved selvmord (O msorgsundersøkelsen) (Dyregrov, 2005). Nivået tilsier at begge ungdomsgruppene har høy grad av posttraumatiske stressreaksjoner (Dyregrov \& Yule, 2006). Brent og medarbeidere (1996) fant at om lag en tredel av unge etterlatte er innom tanken på selvå gjøre det slutt, som er omtrent samme omfang som i denne studien. Som også vist i andre studier er informantenes utbredte konsentrasjonsvansker på sin hovedarena, skolen, sannsynligvis en konsekvens av de store psykososiale belastningene etter selvmordet (Dyregrov, 2006a; Pfeffer et al., 1997; Sethi \& Bhargava, 2003). Det er derfor ikke uventet at studiens unge opplever behov for å bli sett og hjulpet av noen utenfor hjemmet. De ønsker å snakke om vanskene sine til noen som tåler å høre hvor vondt de har det, som bare er der for dem og som kan gi dem spesifikk hjelp ved behov. Denne oppfordringen kan fagfolk gripe gjennom å møte de unge i dypeste respekt og på den enkeltes behov. I tillegg trengs det solid krise og sorgkunnskap. 


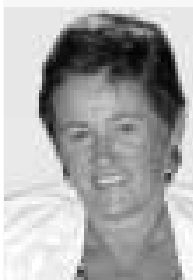

Kari Dyregrov er sosiolog, dr. philos, og arbeider som forsker ved Senter for Krisepsykologi (SfK), Bergen og Nasjonalt folkehelseinstitutt, Oslo.

H un har gjennomført mange forskningsprosjekt knyttet til selvmord, etterlatteproblematikk, sorg og kriser. $H$ un var Landsstyremedlem i LEVE fra 1999-2005, er nå medlem av Fagrådet, og har hatt en sentral rolle i etableringen og oppbyggingen av organisasjonen. I 2007 fikk hun Farberow-prisen for sitt arbeid med sorg og etterlatte ved selvmord, og avsluttet samme år sitt postdoktorarbeid med boken "Sosial nettverksstøtte ved brå død".

\section{Referanser}

Bloom, M., Frankland, J., Thomas, M. \&Robson, K. (2001). Focus groups in social research. London: Sage Publications.

Brent, D. A., Moritz, G., Bridge, J., Perper, J., \& Canobbio, R. (1996). The impact of adolescent suicide on siblings and parents: A longitudinal follow-up. Suicide and Life-Threatening Behavior, 26 , 253-259.

Dyregrov, A., \& Yule, W. (2006). A review of PT SD in children. A commissioned review. Child and Adolescent Mental Health, 11, 176- 184

Dyregrov, K. (2003). The loss of child by suicide, SIDS, and accidents: consequences, needs and provisions of help.

Doktoravhandling. Bergen: HEMIL, Universitetet i Bergen.
Dyregrov, K. (2005). Siblings after suicide: "the forgotten bereaved". Suicide and Life-Threatening Behavior, 35, 714-24.

Dyregrov, K. (2006a). Skolens viktige rolle etter selvmord: ny forskning om unge etterlattes ønsker for hjelp og støtte. Bedre Skole, 1, 46-51.

Dyregrov, K. (2006b). H vordan ønsker unge selvmordsetterlatte å bli møtt av psykologer? - en brukerundersøkelse. Tidsskrift for N orsk Psykologforening, 43, 787-794.

Dyregrov, K. (2008). Psykososiale belastninger for unge etterlatte ved selvmord: $\emptyset$ nsker om bistand fra hjelpeapparatet. Tidsskrift for N orsk Psykologforening, 1, 14-18.

Hogan, N. (1990). Hogan Sibling Inventory of Bereavement. J J. Touliatos, B. Perlmutter \& M. Straus (red.), H andbook of family measurement techniques (s. 524). N ewbury Park, CA: Sage.

H orowitz, M. Wilner, N. \& Alvarez, W. (1979). Impact of Event Scale: A measure of subjective stress. Psychosomatic Medicine, 41, 209-218.

Pfeffer, C. R., Martins, P., Mann, J., Sunkenberg, R. N., Ice, A., Damore, J. P., Gallo, C., Karpenos, I. \& Jiang, H . (1997). Child survivors of suicide: psychosocial characteristics. Journal of American the Academy of Child and Adolescent Psychiatry, 36, 65-74.

Ranheim, U. (2002). Vær der for meg. Vollen: Tell.

Sethi, S., \& Bhargava, S. C. (2003) . Child and adolescent survivors of suicide. Crisis, 24, 4-6.

SSB (2008). Statistisk sentral byrå.

Dødsårsaker.http:/ / www.ssb.no/ dodsar sak/ tab-2007-10-19-08.html (06.02.2008).

Wertheimer, A. (1999) . A special scar. The experiences of people bereaved by suicide. London: Routledge. 5. utg.

\section{Unge Leve}

- Et tilbud for unge i regi av Leve, Landsforeningen for etterlatte ved selvmord

- Målsetting; tilby et forum for unge mennesker som har opplevd å miste noen i selvmord, som kan gi håp og mot til å leve videre

- Organisert via ungdomsrepresentanter i Leves fylkeslag. Ungdomsrepresentantene er kontaktpersoner for unge etterlatte i sine fylker

- Tilbyr samtalegrupper, ungdomskafeer og helgesamlinger for unge etterlatte

- Stiftet ved årsskiftet 2002-2003

- Kontakt: : ungeleve@leve.no

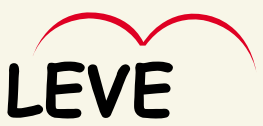

Landsforeningen for etterlatte ved selvmord

LEVEs nye ungdomsbrosjyre basert på Kari Dyregrovs undersøkelse blant unge etterlatte ved selvmord.

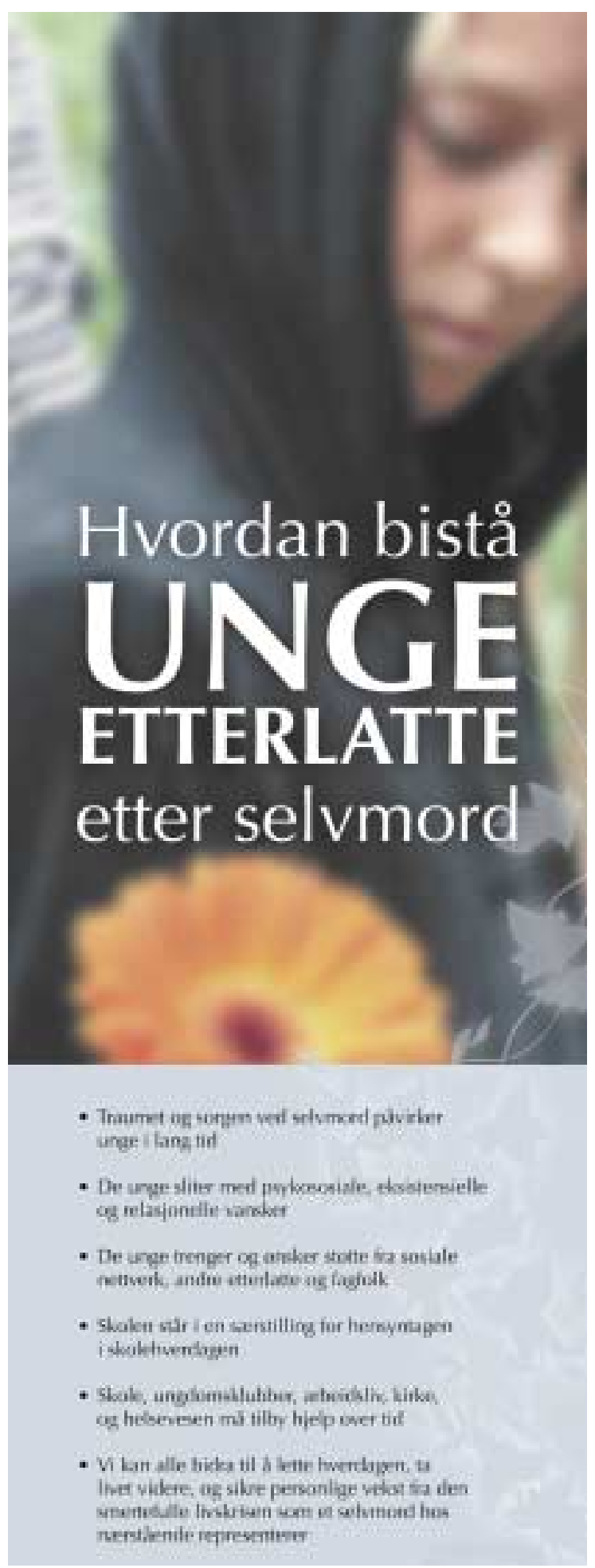

Brosjyren er i hovedsak rettet mot skole, helsevesen og andre miljøer der omsorgspersoner kan møte unge mennesker som har mistet noen ved selvmord. 